\title{
Adaptive Immunity, Inflammation, and Cardiovascular Complications in Type 1 and Type 2 Diabetes Mellitus
}

\author{
Daniela Pedicino, ${ }^{1}$ Giovanna Liuzzo, ${ }^{1}$ Francesco Trotta, ${ }^{1}$ Ada Francesca Giglio, ${ }^{1}$ \\ Simona Giubilato, ${ }^{1}$ Francesca Martini, ${ }^{2}$ Francesco Zaccardi, ${ }^{2}$ Giuseppe Scavone, ${ }^{2}$ \\ Marco Previtero, ${ }^{1}$ Gianluca Massaro, ${ }^{1}$ Pio Cialdella, ${ }^{1}$ Maria Teresa Cardillo, ${ }^{1}$ \\ Dario Pitocco, ${ }^{2}$ Giovanni Ghirlanda, ${ }^{2}$ and Filippo Crea ${ }^{1}$ \\ ${ }^{1}$ Institute of Cardiology, Catholic University, Largo A. Gemelli, 8-00168 Rome, Italy \\ ${ }^{2}$ Diabetes Care Unit, Internal Medicine, Catholic University, Largo A. Gemelli, 8-00168 Rome, Italy
}

Correspondence should be addressed to Giovanna Liuzzo; giovanna.liuzzo@gmail.com

Received 5 March 2013; Accepted 5 April 2013

Academic Editor: Norman Cameron

Copyright @ 2013 Daniela Pedicino et al. This is an open access article distributed under the Creative Commons Attribution License, which permits unrestricted use, distribution, and reproduction in any medium, provided the original work is properly cited.

Diabetes mellitus (DM) is a pandemics that affects more than 170 million people worldwide, associated with increased mortality and morbidity due to coronary artery disease (CAD). In type 1 (T1) DM, the main pathogenic mechanism seems to be the destruction of pancreatic $\beta$-cells mediated by autoreactive T-cells resulting in chronic insulitis, while in type 2 (T2) DM primary insulin resistance, rather than defective insulin production due to $\beta$-cell destruction, seems to be the triggering alteration. In our study, we investigated the role of systemic inflammation and T-cell subsets in T1- and T2DM and the possible mechanisms underlying the increased cardiovascular risk associated with these diseases.

\section{Introduction}

Diabetes mellitus (DM) is a pandemics that affects more than 170 million people worldwide $[1,2]$, associated with increased mortality and morbidity due to coronary artery disease (CAD) [3,4]. Patients with DM have 2- to 4-fold increase in risk of CAD and up to 3-fold increase in mortality and carry the same level of risk for subsequent acute coronary events as nondiabetic patients with previous myocardial infarction (MI). DM also worsens early and late outcomes in acute coronary syndromes (ACS) $[5,6]$. Indeed, DM is a prothrombotic condition, associated with inflammation, altered innate immunity, and impaired endothelial function $[7,8]$. However, the mechanisms responsible for the higher cardiovascular risk that accompanies DM are multiple and still largely unknown.

In type 1 (T1) DM, the main pathogenic mechanism seems to be the destruction of pancreatic $\beta$-cells mediated by autoreactive T-cells resulting in chronic insulitis. Thus, the chronic inflammation of pancreatic islets plays a pivotal role in the development of the disease [9].

In type 2 (T2) DM, primary insulin resistance, rather than defective insulin production due to $\beta$-cells destruction, seems to be the triggering alteration. Insulin resistance leads to a perturbation in the lipid homeostasis, cytokines, and adipokines production, resulting in increased systemic inflammation, with higher levels of inflammatory markers such as C-reactive protein (CRP), interleukin (IL)-6, and tumor necrosis factor (TNF)- $\alpha[7,10-16]$.

Inflammation and immunity play also a key role in the pathogenesis of atherosclerosis and its complications. Immune responses are a cornerstone in the mechanisms of endothelial activation, plaque development, and rupture, as demonstrated by the correlations between levels of inflammatory markers or certain lymphocyte population and the risk of occurrence of cardiovascular (CV) events [17-21]. Several studies documented a role for T-cell subset imbalance in the induction of an altered glucose homeostasis both in 
T1DM and in T2DM [22-42]. Recent experimental models demonstrated that interferon (IFN)- $\gamma$-producing cells are present in elevated number in adipose tissue of obese mice and have a role in promoting a loss in glucose homeostasis, mostly derived by the induction of visceral adipose tissue inflammation and endothelial dysfunction [24, 25]. Among T lymphocytes, $\mathrm{CD} 4{ }^{+} \mathrm{CD} 28^{\text {null }}$ cells represent a subpopulation producing high levels of IFN- $\gamma$, showing resistance to apoptosis, and exerting direct cytolytic effects on endothelial cells and proapoptotic effects on smooth muscle cells [26-30]. Our group has previously shown that circulating $\mathrm{CD} 4^{+} \mathrm{CD} 28^{\text {null }}$ T-cell frequency higher than $4 \%$ is associated with a worse outcome of ACS. Moreover, for the first time, we specifically demonstrated that in T2DM patients $\mathrm{CD} 4{ }^{+} \mathrm{CD} 28^{\text {null }}$ T-cells are expanded and are associated both with the occurrence of a first CV event and with a higher risk of recurrences after an ACS [31, 32]. However, data on this particular T-cell subset and its implication in diabetes are still lacking; particularly, there are no studies exploring the role of $\mathrm{CD} 4^{+} \mathrm{CD} 28^{\text {null }} \mathrm{T}$ cells in T1DM and its complications.

The role of $\mathrm{CD} 4{ }^{+} \mathrm{CD} 25^{+}$Foxp $3^{+}$regulatory T-cells (Tregs) in both T1DM and T2DM has also been investigated. In T2DM, Tregs seem to play a fundamental part in the regulation of body weight, adipocyte hypertrophy, glucose tolerance insulin resistance, and thus in the disease progression [24, 33, 34]. Also, in T1DM, Tregs seem to be involved in the onset and development of the disease, as suggested by studies documenting that alteration of Treg compartment may cause or predispose to autoimmunity [35-37]. The possible mechanism linking Tregs, autoimmunity, and T1DM has been evaluated in recent studies showing that Tregs in the pancreas of NOD mice are prone to apoptosis and fail to control autoimmune responses leading to diabetes [38]. Tregs have also a role in the suppression of the inflammatory and immune responses leading to CV diseases [39, 40]. Recently, a powerful inhibition of atherosclerosis mediated by naturally arising Tregs has been demonstrated in mouse models [41]. Nevertheless, the last decade has seen controversial reports on defects in frequency or function of Tregs in T1DM [42].

Aim of the present study is to investigate the role of systemic inflammation and T-cell subsets in T1 and T2DM and the possible mechanisms underlying the increased CV risk, which characterize these conditions.

\section{Materials and Methods}

\subsection{Study Population}

2.1.1. DM Patients. We enrolled 110 patients with a diagnosis of DM defined according to ADA criteria, 55 of them affected by T1DM and 55 patients with T2DM. Exclusion criteria were (1) age $>80$ years $(n=37)$; (2) evidence of inflammatory or infectious diseases, malignancies, immunologic, or hematological disorders $(n=34)$; (3) treatment with antiinflammatory drugs other than low-dose aspirin $(n=32)$.

Clinical features were carefully recorded, including classical cardiovascular risk factors, age at diagnosis of DM, duration of DM, glycosylated haemoglobin A1c (HbA1c), and body mass index (BMI). A complete cardiovascular screening was performed, including a standard 12-lead EKG, a treadmill EKG stress test, an Echo-color Doppler of carotid arteries, the ankle brachial pressure index, and an Echo-color Doppler to exclude lower-limb arterial disease. Microvascular complications, including diabetic nephropathy, neuropathy, and retinopathy, were also assessed. To address the presence of these possible complications, a complete neurological examination performed by certified independent neurologists, a quantitative measurement of urine protein excretion in a sample obtained from $24 \mathrm{~h}$ urine collection, and a fundoscopy performed by certified independent ophthalmologists were used.

2.1.2. Controls. As control group, we studied 60 individuals without overt cardiovascular disease and DM, who were screened in our outpatients clinic for cardiovascular prevention. We ascertained traditional cardiovascular risk factors including age, blood pressure, smoking status, family history of MI, and total, LDL, HDL cholesterol and triglycerides levels.

All individuals gave their written informed consent. The Ethics Committee of the catholic University of Rome approved the study.

2.2. Anthropometric Measurements. Anthropometric measurements were taken according to standardized procedures after an overnight fasting, with the patient wearing indoor clothes without shoes. Height was measured in centimeters using a stadiometer. Weight was measured with Tanita bioimpedance balance (Tanita International Division, West Dryton, UK). Waist circumference was measured just above the uppermost lateral border of the right ileum using the National Health and Nutrition Examination Survey protocol [43].

2.3. Blood Sampling. Venous blood samples were taken at the time of patient enrollment.

Total and differential white blood cell counts and T-cell subset distribution were analyzed on fresh blood samples. Whole blood samples were also used to assess HbA1c levels, whereas coded serum samples were stored at $-70^{\circ} \mathrm{C}$ and analyzed for high-sensitivity C-reactive protein (hs-CRP) in a single batch at the end of the study by laboratory staff unaware of the clinical data.

2.4. T-Cell Analysis. Total and differential white blood cell counts were obtained with a Bayer $\mathrm{H}^{*} 3$-hematology analyzer using automated cytochemistry in flow.

T-cell subsets were assessed by flow cytometry. Peripheral blood mononuclear cells (PBMCs) were isolated from heparinized whole blood samples by standard gradient centrifugation over Ficoll-Hypaque (GE Healthcare Bio-Sciences, Piscataway, NJ, USA), washed twice in PBS, then resuspended to a density of $10^{5}$ cells $/ \mathrm{mL}$, stained with the appropriate monoclonal antibodies for cell surface staining, and fixed. When indicated, PBMCs were permeabilized by permeabilization buffer (eBioscience, San Diego, CA, USA) for 
intracellular staining. Isotype controls were given to enable correct compensation and confirm antibody specificity. In all cases, nonspecific staining with isotype-matched control $\mathrm{mAb}$ was $<1 \%$; the intra- and interassay variability was $<10 \%$. Analyses of stained cells were performed using an FC500 Flow Cytometry System (Beckman Coulter, Fullerton, CA, USA). CXP ACQUISITION and CXP ANALYSIS software packages (Beckman Coulter, Fullerton, CA, USA) were used for data acquisition and analysis, respectively. All T-cell subsets analyzed were expressed as a percentage of the entire population of $\mathrm{CD} 4^{+} \mathrm{T}$-cells.

2.4.1. Frequency of Different T-Cell Subsets. $\mathrm{CD} 4^{+} \mathrm{CD} 28^{\text {null }}$ $\mathrm{T}$-cell frequency was determined using anti-CD4-fluorescin isothiocyanate- (FITC-) conjugated $\mathrm{mAb}$ and anti-CD28phycoerythrin- $\mathrm{Cy} 5$ (PC5-) conjugated mAb (both Beckman Coulter, Fullerton, CA, USA).

Treg cells were defined as $\mathrm{CD} 4^{+} \mathrm{Foxp}^{+}{ }^{+} \mathrm{T}$-cells. To this purpose, PBMCs were stained with anti-CD4-FITC mAb. After cell surface staining, cell fixation, and permeabilization, cells were stained with the intracellular PE-conjugated antiFoxp3 mAB (eBioscience, San Diego, CA, USA) according to the manufacturer's instructions.

A cutoff value $\geq 4 \%$ was chosen to define patients with high frequency of $\mathrm{CD} 4^{+} \mathrm{CD} 28^{\text {null }}$ T-cells, because $4 \%$ represents the 90th percentile of distribution in healthy individuals. This cutoff was also validated in our control group ( median $=1.5 \%$; 90th percentile $=4.0 \%)$.

A cutoff value $\leq 5 \%$ was chosen to define patients with low frequency of Tregs, because 5\% represents the 10th percentile of distribution in our control group (median $=7.8 \%$; 10th percentile $=5.0 \%$ ).

The $\mathrm{CD} 4^{+} \mathrm{CD} 28^{\text {null }} /$ Treg balance was evaluated by the ratio of $\mathrm{CD}^{+} \mathrm{CD} 28^{\text {null }}$ T-cells to $\mathrm{CD} 4^{+} \mathrm{Foxp}^{+}$T-cells; a cutoff value $\geq 1.1$ was chosen to define an alteration of the balance, because this value represents the 99th percentile of distribution in our control group (median $=0.21$; 99th percentile $=1.1 \%$ ).

2.5. Measurements of hs-CRP and HbA1c. We measured hsCRP concentrations using an ultrasensitive nephelometric method (Siemens HealthCare Diagnostic BN System, Deerfield, IL, USA). The working range of the assay was 0.175 to $1100 \mathrm{mg} / \mathrm{L}$, and the coefficient of variation was $<5 \%$. The median normal value for hs-CRP was $0.8 \mathrm{mg} / \mathrm{L}$, with $90 \%$ of normal values $<3 \mathrm{mg} / \mathrm{L}$.

HbAlc was assessed by high-performance liquid chromatography, using Diamat BioRad (BioRad, Milan, Italy). The HbAlc reference range was $4.3-5.9 \%$.

2.6. Statistical Analysis. Because $\mathrm{CD} 4^{+} \mathrm{CD} 28^{\text {null }}$ and Treg frequencies and hs-CRP values did not follow a normal distribution, according to Kolmogorov-Smirnov, data were expressed as median and range, and nonparametric tests were used: the Kruskal-Wallis test with the Dunn's multiple pairwise comparison for comparisons among groups and the Spearman's rank test for correlations. The remaining continuous variables were expressed as mean $\pm \mathrm{SD}$ and were compared using 1-way ANOVA for repeated measures, with the Bonferroni correction for multiple pairwise comparisons. Proportions were compared using the chi-square test.

A two-tailed $P$ value $<0.05$ was considered statistically significant. Statistical analysis was performed with SPSS 18.0 software (SPSS Inc., Chicago, Illinois, USA).

\section{Results}

Characteristics of study population are reported in Table 1.

As compared with both T2DM patients and controls, T1DM patients were younger $(P<0.001$ for both comparisons), and exhibited higher rate of hypercholesterolemia ( $P<0.05$ for both comparisons). As compared with T2DM, T1DM patients had a longer disease duration $(P=0.020)$, were more often treated with insulin $(P<0.001)$, and had higher levels of total cholesterol $(P=0.045)$ and HDL cholesterol $(P<0.001)$. They also had higher levels of HDL cholesterol than controls $(P<0.001)$.

T2DM patients exhibited higher rate of family history of IHD ( $P=0.001$ versus controls). As compared with T1DM, T2DM patients were more often treated with oral antidiabetic drugs $(P<0.001)$ and had higher BMI and waist circumference $(P<0.001$ for both comparisons), higher triglycerides levels $(P=0.015)$, and higher rate of macrovascular complications $(P=0.005)$.

3.1. Frequencies of T-Cell Subsets. No differences were found in total T-cell and $\mathrm{CD} 4^{+} \mathrm{T}$-cell counts among groups (Table 1).

$\mathrm{CD} 4^{+} \mathrm{CD} 28^{\text {null }}$ T-cell frequency was significantly higher in T1DM than in T2DM and in controls $(P=0.001$ and $P<$ 0.001 , resp. $)$ and it was higher in T2DM than in controls $(P<$ 0.001) (Table 1 and Figure 1(a)).

In sharp contrast, Treg frequency was significantly lower in T1DM than in T2DM and in controls $(P<0.001$ for both comparisons), and it was lower in T2DM than in controls $(P<0.001)$ (Table 1 and Figure $1(b))$.

3.2. Imbalance between Effector and Regulatory T-Cells in T1DM Patients. In T1DM, a statistically significant negative correlation was detected between $\mathrm{CD} 4^{+} \mathrm{CD} 28^{\text {null }} \mathrm{T}$-cell frequency and Tregs $(R=-0.28 ; P=0.015)$, likely suggesting the preferential association of increased $\mathrm{CD} 4{ }^{+} \mathrm{CD} 28^{\text {null }} \mathrm{T}$ cell immune response with impaired Treg function in single T1DM patients (Figure 2(a)). No correlation was observed in T2DM (Figure 2(b)).

The significance of increased $\mathrm{CD} 4^{+} \mathrm{CD} 28^{\text {null }} \mathrm{T}$-cell frequency and decreased Treg cells was further explored by calculating the $\mathrm{CD} 4^{+} \mathrm{CD} 28^{\text {null }} /$ Treg cell percentage ratio in each subject. There was a strikingly higher $\mathrm{CD} 4{ }^{+} \mathrm{CD} 28^{\text {null }} /$ Treg ratio in T1DM patients than in T2DM patients and in controls $(P<0.001$ for all comparisons), and a higher ratio in T2DM patients than in controls $(P<0.001)$ (Table 1 and Figure 3$)$.

3.3. Systemic Inflammation. We have also studied low-grade systemic inflammation assessing the serum levels of hs-CRP. 
TABLE 1: Clinical characteristics of study population.

\begin{tabular}{|c|c|c|c|c|}
\hline & T1DM & T2DM & Controls & $P$ value \\
\hline Number of patients & 55 & 55 & 60 & \\
\hline $\operatorname{Sex}(M / F)$ & $37 / 18$ & $36 / 19$ & $34 / 26$ & 0.118 \\
\hline Age $($ mean $\pm \mathrm{SD})$ & $45.2 \pm 14$ & $62 \pm 10$ & $55.7 \pm 11.8$ & $0.037^{\mathrm{a}}$ \\
\hline \multicolumn{5}{|l|}{ Risk factors } \\
\hline Hypercholesterolemia, $n$ (\%) & $31(56 \%)$ & $20(36 \%)$ & $17(28 \%)$ & $0.048^{\mathrm{b}}$ \\
\hline Hypertension, $n(\%)$ & $26(47 \%)$ & $37(67 \%)$ & $48(80 \%)$ & $0.015^{\mathrm{c}}$ \\
\hline Smoke, $n(\%)$ & $22(40 \%)$ & $19(35 \%)$ & $26(43 \%)$ & 0.63 \\
\hline Family history of IHD, $n(\%)$ & $26(47 \%)$ & $37(67 \%)$ & $18(30 \%)$ & $0.002^{\mathrm{d}}$ \\
\hline \multicolumn{5}{|l|}{ Medications } \\
\hline Oral antidiabetic drugs, $n(\%)$ & $8(15 \%)$ & $44(80 \%)$ & NA & $<0.001$ \\
\hline Insulin, $n(\%)$ & $54(98 \%)$ & $15(27 \%)$ & NA & $<0.001$ \\
\hline Statins, $n(\%)$ & $25(45 \%)$ & $24(44 \%)$ & $7(12 \%)$ & $<0.001^{\mathrm{e}}$ \\
\hline \multicolumn{5}{|l|}{ Disease complications } \\
\hline $\begin{array}{l}\text { Microvascular complications } \\
\text { (nephropathy, neuropathy, and retinopathy) }\end{array}$ & $25(45 \%)$ & $28(51 \%)$ & NA & 0.33 \\
\hline $\begin{array}{l}\text { Macrovascular complications } \\
\text { (CAD, PVD, and cerebrovascular diseases) }\end{array}$ & $18(33 \%)$ & $37(67 \%)$ & NA & 0.005 \\
\hline \multicolumn{5}{|l|}{ Antropometric parameters $($ mean $\pm \mathrm{SD})$} \\
\hline $\operatorname{BMI}\left(\mathrm{kg} / \mathrm{m}^{2}\right)$ & $24.4 \pm 3.5$ & $27.8 \pm 5.2$ & $25.9 \pm 3.8$ & $0.003^{\mathrm{f}}$ \\
\hline Waist circumference $(\mathrm{cm})$ & $81 \pm 10$ & $93 \pm 12.6$ & $79 \pm 7$ & $0.002^{\mathrm{f}}$ \\
\hline $\operatorname{HbAlc}(\%)$ & $7.4 \pm 0.4$ & $7.6 \pm 1.4$ & NA & 0.418 \\
\hline Mean duration of DM (years) & $18.5 \pm 10.4$ & $13.5 \pm 8.9$ & NA & 0.020 \\
\hline \multicolumn{5}{|l|}{ Laboratory assay (mean \pm SD) } \\
\hline Total cholesterol (mg/dL) & $196.5 \pm 30$ & $178.5 \pm 49.3$ & $183.5 \pm 43.5$ & $0.018^{g}$ \\
\hline $\mathrm{LDL}(\mathrm{mg} / \mathrm{dL})$ & $100.9 \pm 44.7$ & $104.6 \pm 37.8$ & $112.2 \pm 40.1$ & 0.65 \\
\hline HDL (mg/dL) & $62 \pm 13.7$ & $49.6 \pm 11$ & $50.3 \pm 15.6$ & $<0.001^{\mathrm{a}}$ \\
\hline Triglycerides $(\mathrm{mg} / \mathrm{dL})$ & $99.2 \pm 38.4$ & $126.6 \pm 61.3$ & $111.1 \pm 60.7$ & $0.029^{\mathrm{h}}$ \\
\hline Lymphocyte count $\left(10^{9} / \mathrm{L}\right)$ & $1.5 \pm 0.5$ & $1.6 \pm 0.5$ & $1.9 \pm 0.6$ & 0.4 \\
\hline Total CD4 ${ }^{+}$T-cell frequency (\%) & $50.3 \pm 20.2$ & $50.5 \pm 19.7$ & $50.4 \pm 23.6$ & 0.4 \\
\hline hs-CRP (mg/L), median (range) & $1.0(0.2-9.1)$ & $3.4(0.2-21.9)$ & $1.1(0.2-7.9)$ & $<0.001^{\mathrm{i}}$ \\
\hline \multicolumn{5}{|l|}{ Frequency of different T-cell subsets } \\
\hline \multicolumn{5}{|l|}{$\begin{array}{l}\text { Expressed as percentage of the entire } \mathrm{CD}^{+} \mathrm{T} \text {-cell } \\
\text { population, median (range) }\end{array}$} \\
\hline $\mathrm{CD} 4^{+} \mathrm{CD} 28^{\text {null }}$ T-cell $(\%)$ & $6.9(0.4-32.8)$ & $3.6(0.2-22.5)$ & $1.5(0.2-8.0)$ & $<0.001^{\mathrm{j}}$ \\
\hline $\mathrm{CD}^{+}{ }^{+}$Foxp $3^{+}$T-cell (Treg) (\%) & $1.5(0.5-3.3)$ & $2.1(0.3-12.3)$ & $7.8(4.1-12.0)$ & $<0.001^{\mathrm{k}}$ \\
\hline $\mathrm{CD} 4^{+} \mathrm{CD} 28^{\text {null }} /$ Treg ratio & $4.3(0.7-26.4)$ & $1.3(0.1-66.5)$ & $0.2(0.1-1.3)$ & $<0.001^{1}$ \\
\hline
\end{tabular}

DM: diabetes mellitus; IHD: ischemic heart disease; CAD: coronary artery disease; PVD: peripheral vascular disease; BMI: body mass index; HbAlc: glycosylated haemoglobin Alc; hs-CRP: high-sensitivity C-reactive protein.

${ }^{a} P<0.001$ T1DM versus T2DM and controls.

${ }^{\mathrm{b}} P<0.05$ T1DM versus T2DM and controls.

${ }^{\mathrm{c}} P<0.001$ controls versus T1DM.

${ }^{\mathrm{d}} P<0.001 \mathrm{~T} 2 \mathrm{DM}$ versus controls.

${ }^{\mathrm{e}} P<0.05$ T1DM and T2DM versus controls.

${ }^{\mathrm{f}} P<0.001 \mathrm{~T} 2 \mathrm{DM}$ versus T1DM and controls.

${ }^{\mathrm{g}} P<0.05$ T1DM versus T2DM.

${ }^{\mathrm{h}} P<0.05 \mathrm{~T} 2 \mathrm{DM}$ versus T1DM.

${ }^{\mathrm{i}} P<0.001 \mathrm{~T} 2 \mathrm{DM}$ versus T1DM and controls.

${ }^{\mathrm{j}} P<0.001 \mathrm{~T} 1 \mathrm{DM}$ (higher frequency) versus T2DM and controls; also, $P<0.001 \mathrm{~T} 2 \mathrm{DM}$ versus controls.

${ }^{\mathrm{k}} P<0.001$ T1DM (lower frequency) versus T2DM and controls; also, $P<0.001 \mathrm{~T} 2 \mathrm{DM}$ versus controls.

${ }^{1} P<0.001$ T1DM versus T2DM and controls; also, $P<0.001$ T2DM versus controls. 


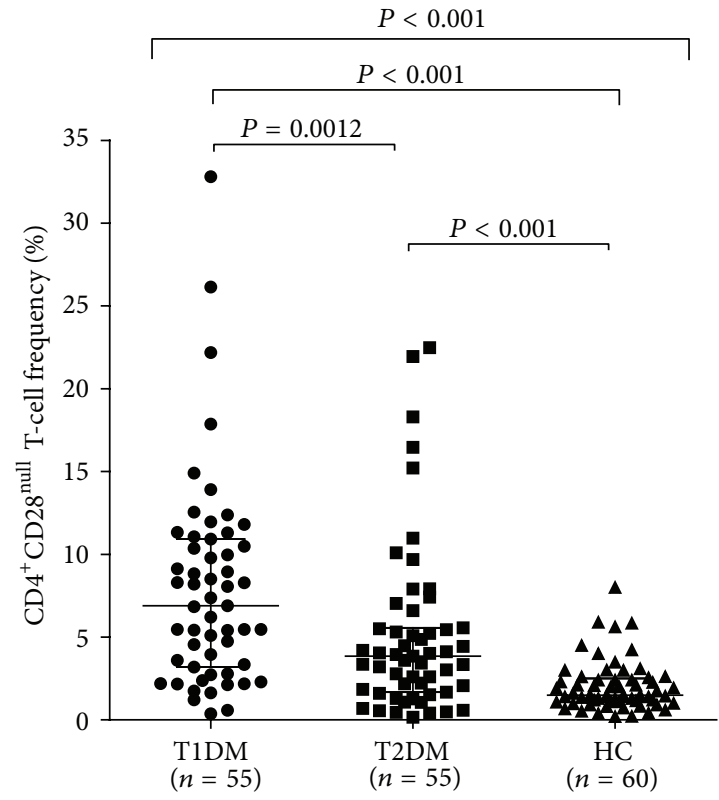

(a)

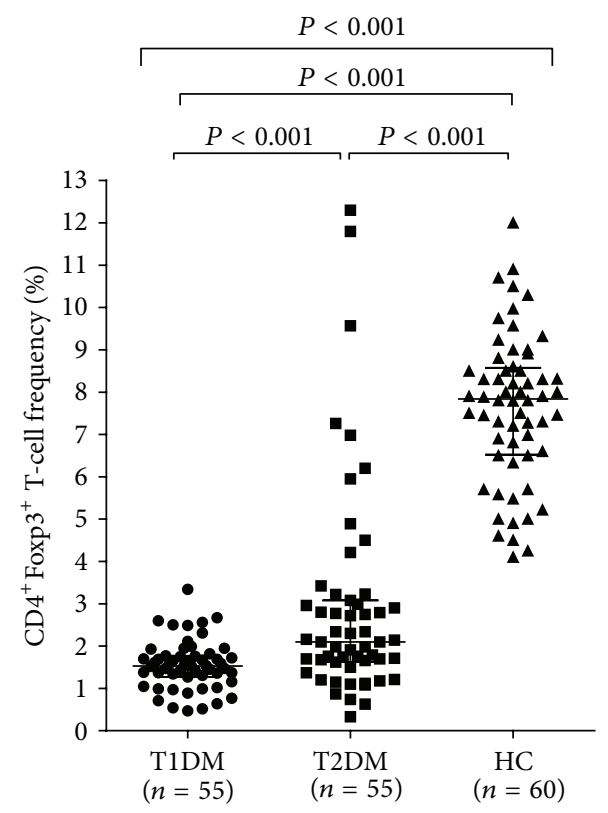

(b)

FIgURE 1: Frequencies of T-cell subsets in different groups. T1DM and T2DM groups were defined according to ADA criteria, while controls were individuals without overt cardiovascular disease and DM. Frequencies of T-cells were determined by two-color flow cytometry. Data are presented as single data points. (a) $\mathrm{CD} 4^{+} \mathrm{CD} 28^{\text {null }} \mathrm{T}$-cell frequencies in different groups. $\mathrm{CD} 4^{+} \mathrm{CD} 28^{\text {null }} \mathrm{T}$-cell frequency was significantly higher in T1DM than in other groups, and it was higher in T2DM than in controls. (b) $\mathrm{CD} 4^{+} \mathrm{FoxP} 3^{+} \mathrm{T}$-cell frequencies in different groups. $\mathrm{CD}^{+}{ }^{+}$FoxP3 ${ }^{+} \mathrm{T}$-cell frequency was significantly lower in T1DM than in other groups, and it was lower in T2DM than in controls.

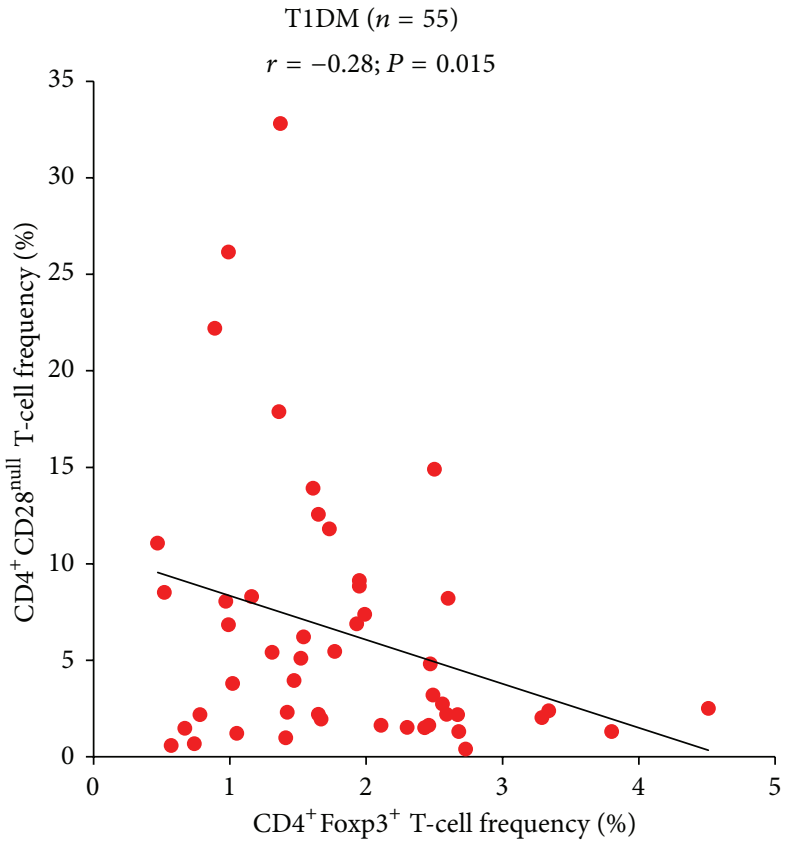

(a)

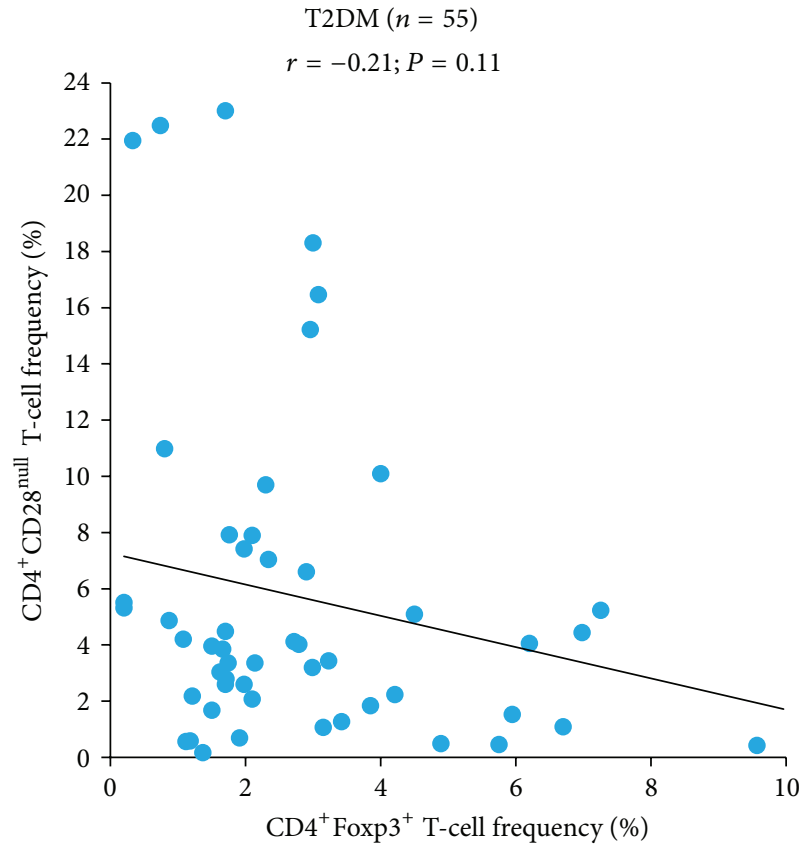

(b)

FIGURE 2: Correlation between $\mathrm{CD} 4^{+} \mathrm{CD} 28^{\text {null }} \mathrm{T}$-cell and $\mathrm{CD} 4^{+} \mathrm{FoxP}^{+} \mathrm{T}$-cell frequencies in T1DM and T2DM patients. Data are presented as single data points. (a) In T1DM patients, a significant negative correlation was found between $\mathrm{CD} 4^{+} \mathrm{CD} 28^{\text {null }} \mathrm{T}$-cell and $\mathrm{CD} 4^{+}$FoxP3 ${ }^{+} \mathrm{T}$-cell frequencies. (b) In T2DM patients, no correlation was found between $\mathrm{CD} 4^{+} \mathrm{CD} 28^{\text {null }} \mathrm{T}$-cell and $\mathrm{CD} 4^{+}$FoxP3 ${ }^{+} \mathrm{T}_{\text {-cell frequencies. }}$ 


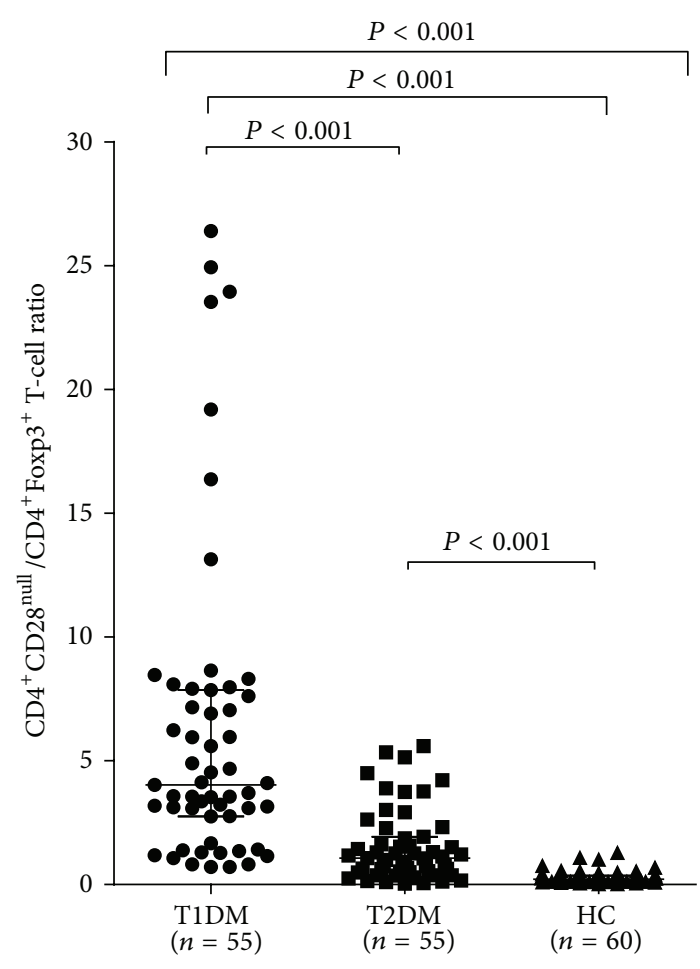

FIGURE 3: $\mathrm{CD}^{+} \mathrm{CD} 28^{\text {null }} / \mathrm{CD} 4^{+} \mathrm{FoxP}^{+}$percentage ratio in different groups. T1DM, T2DM, and control groups were defined as in Figure 1. Data are presented as single data points. A significantly higher $\mathrm{CD}^{+} \mathrm{CD} 28^{\text {null }} / \mathrm{CD} 4^{+} \mathrm{FoxP}^{+}$ratio was detected in T1DM patients than in $\mathrm{T} 2 \mathrm{DM}$ and in controls. $\mathrm{CD} 4^{+} \mathrm{CD} 28^{\text {null }} / \mathrm{CD} 4^{+} \mathrm{FoxP}^{+}$ratio was also higher in T2DM patients than in controls.

Hs-CRP was significantly higher in T2DM than in the other groups $(P<0.001$ for all comparisons). Of note, T1DM patients had similar hs-CRP levels than controls $(P=0.99)$ (Table 1, Figure 4).

3.4. T-Cell Frequencies and hs-CRP Levels according to Metabolic Factors, Disease Duration, and Complications. In T1DM patients, no correlations were observed between $\mathrm{CD} 4^{+} \mathrm{CD} 28^{\text {null }}$ T-cell and/or Treg frequency and metabolic factors, disease duration, and complications.

In T2DM patients, $\mathrm{CD} 4^{+} \mathrm{CD} 28^{\text {null }} \mathrm{T}$-cell frequency was positively correlated $(r=0.47 ; P<0.001)$, and Treg frequency was negatively correlated $(r=-0.41 ; P=0.002)$ with disease duration (Figures 5(a) and 5(b)); moreover, $\mathrm{CD} 4^{+} \mathrm{CD} 28^{\text {null }}$ T-cell frequency was positively correlated $(r=0.41 ; P=0.008)$, and Treg frequency was negatively correlated $(r=-0.52 ; P=0.001)$ with HbAlc (Figures 6(a) and 6(b)); finally, a statistically significant correlation was found between hs-CRP levels and BMI $(r=0.47 ; P<0.001)$ (Figure 7).

To investigate the potential relationship between $\mathrm{CD} 4^{+} \mathrm{T}$ cell subset alteration with the types of diabetic complications, we compared the levels of $\mathrm{CD} 4^{+} \mathrm{CD} 28^{\text {null }} \mathrm{T}$-cells and Tregs in T1DM and T2DM patients with or without different types of complications. No differences were observed among T1DM

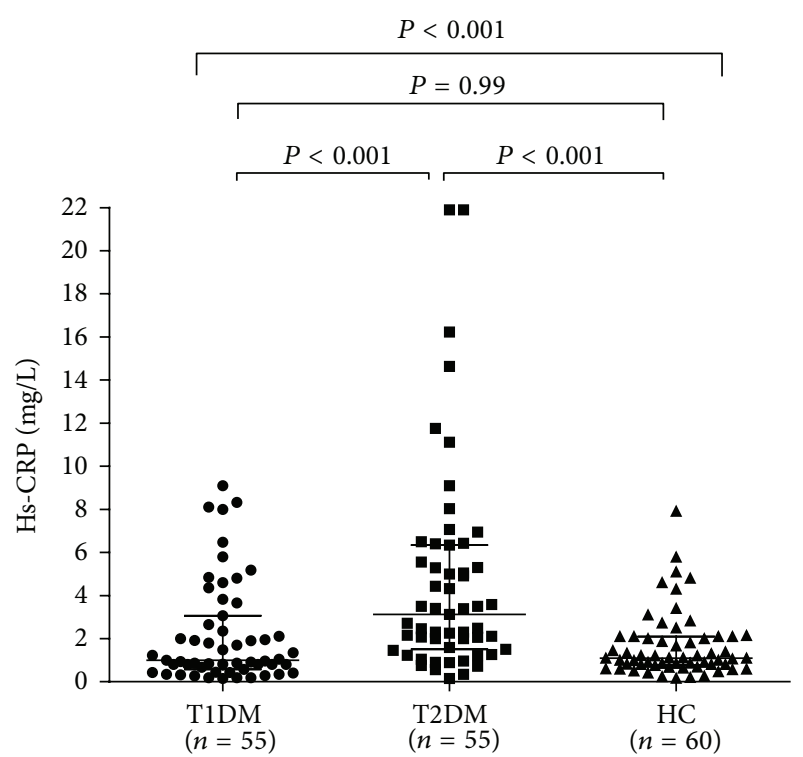

FIGURE 4: Serum hs-CRP levels in different groups. Data are presented as single data points. Serum hs-CRP levels were significantly higher in T2DM than in the other groups. No difference was found between T1DM patients and controls.

patients with or without micro- or macrovascular complications. $\mathrm{CD}^{+} \mathrm{CD} 28^{\text {null }} \mathrm{T}$-cells and Treg were also similar in T2DM patients with or without micro- or macrovascular complications, while hs-CRP levels were significantly higher in T2DM patients with macrovascular complications (median 4.3, range 0.5-21.9 versus median 2.0, range 0.5-14.6; $P=0.047)$.

These data suggest that the changes of $\mathrm{CD} 4^{+} \mathrm{T}$-cell subsets in T1DM patients may happen before the occurrence of complications and at the early stage of disease. In contrast, in T2DM patients, $\mathrm{CD} 4^{+}$T-cell subset alteration might be the consequence of disease duration and metabolic control.

\section{Discussion}

$\mathrm{DM}$ and CAD are two pathological conditions closely related to each other; as demonstrated by the fact that, in the evaluation of cardiovascular risk, DM is considered as an equivalent of established CAD [3,4]. Atherothrombosis is the leading cause of death among diabetic patients, accounting for about $80 \%$ of mortality in this population, which comprehends more than 150 million people worldwide; therefore, the burden of DM-related CAD constitutes a major health problem $[3,4]$.

Several mechanisms could be involved in the pathogenesis of diabetes-related vascular complications, including oxidative stress, vascular damage due to advanced end glycation products (AGE), and glucose-induced inflammation $[7,8,13,14]$.

It is well established that both T1DM and T2DM are associated with a systemic inflammatory state [44-46]. The main features of inflammation, however, could be different between T1DM and T2DM, due to their different pathogenesis. In fact, T1DM onset is related to pancreatic $\beta$-cells 


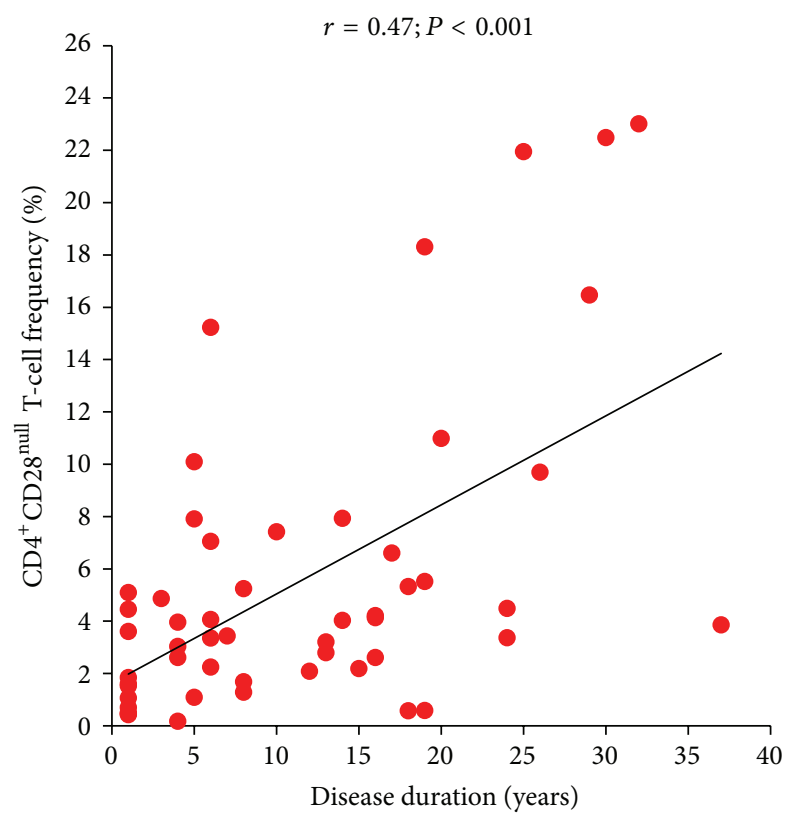

(a)

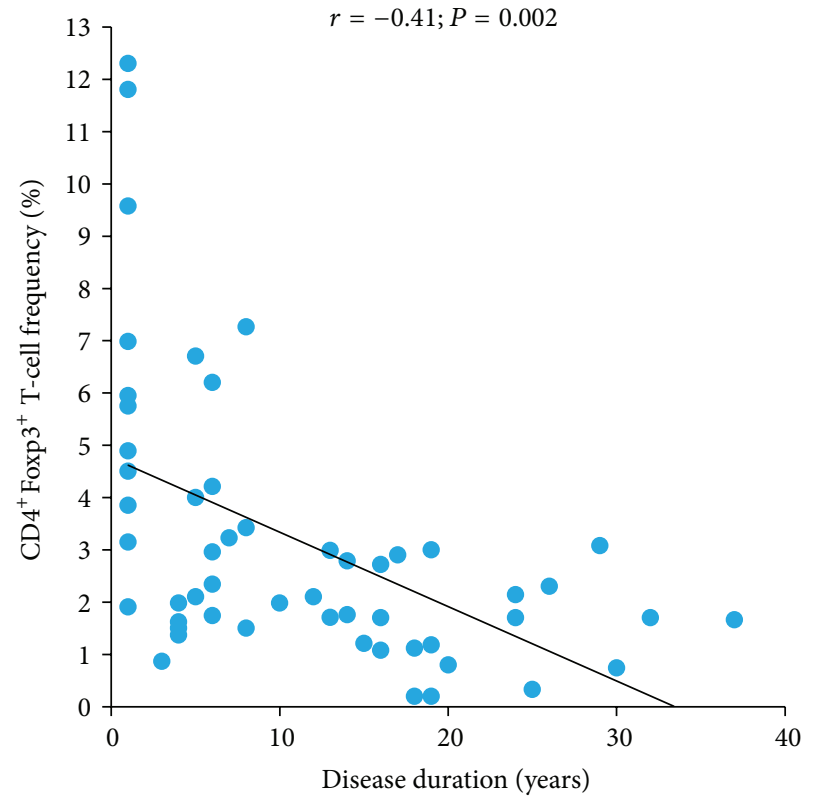

(b)

FIgURE 5: Correlation between T-cell subsets and disease duration in T2DM patients. T2DM patients were defined as in Figure 1. Data are presented as single data points. (a) $\mathrm{CD} 4^{+} \mathrm{CD} 28^{\text {null }} \mathrm{T}$-cell frequency positively correlates with disease duration in $\mathrm{T} 2 \mathrm{DM}$ patients. (b) $\mathrm{CD}^{+} \mathrm{FoxP}^{+} \mathrm{T}$-cell negatively correlates with disease duration in T2DM patients.

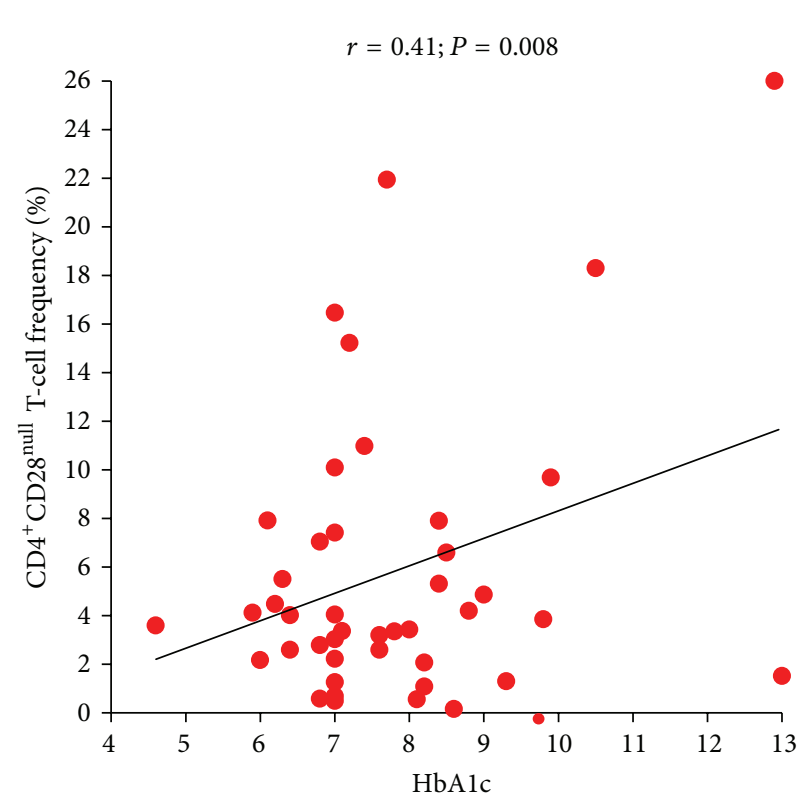

(a)

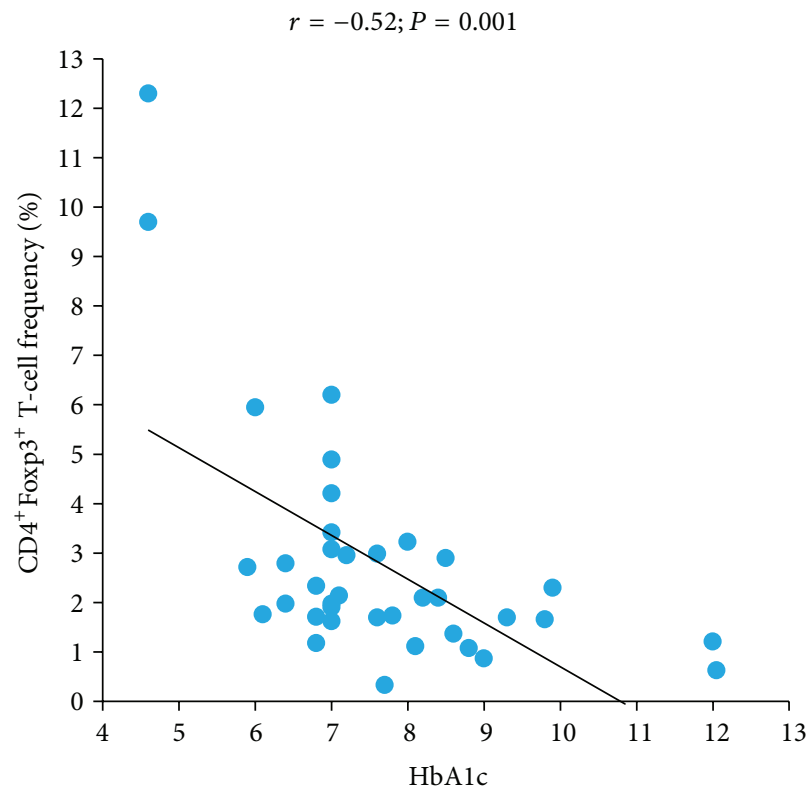

(b)

FIGURE 6: Correlation between T-cell subsets and serum HbA1c levels in T2DM patients. T2DM patients were defined as in Figure 1. Data are presented as single data points. (a) $\mathrm{CD} 4^{+} \mathrm{CD} 28^{\text {null }} \mathrm{T}$-cell frequency positively correlates with $\mathrm{HbAlc}$ in $\mathrm{T} 2 \mathrm{DM}$ patients. (b) $\mathrm{CD} 4^{+} \mathrm{FoxP} 3^{+}$ T-cell negatively correlates with HbAlc in T2DM patients.

destruction by autoreactive T-cells and subsequent insulin deficiency leading to the metabolic alterations of the disease $[9,45]$, while the pathogenesis of T2DM involves primarily insulin resistance, rather than absolute insulin deficiency, deriving from metabolic alterations in insulin-responsive tissues and resulting in a complex alteration of lipid and glucose homeostasis $[17,18]$. These perturbations lead to an imbalance in cytokines and adipokines production resulting in increased systemic inflammation [13, 14]. Conversely, systemic inflammation can itself predispose to the onset of 


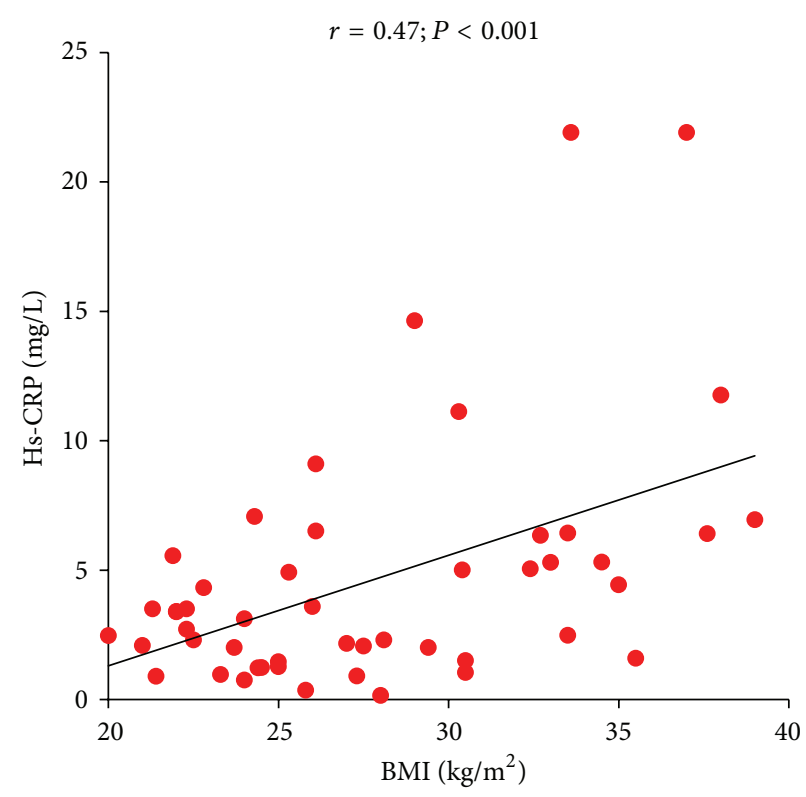

(a)

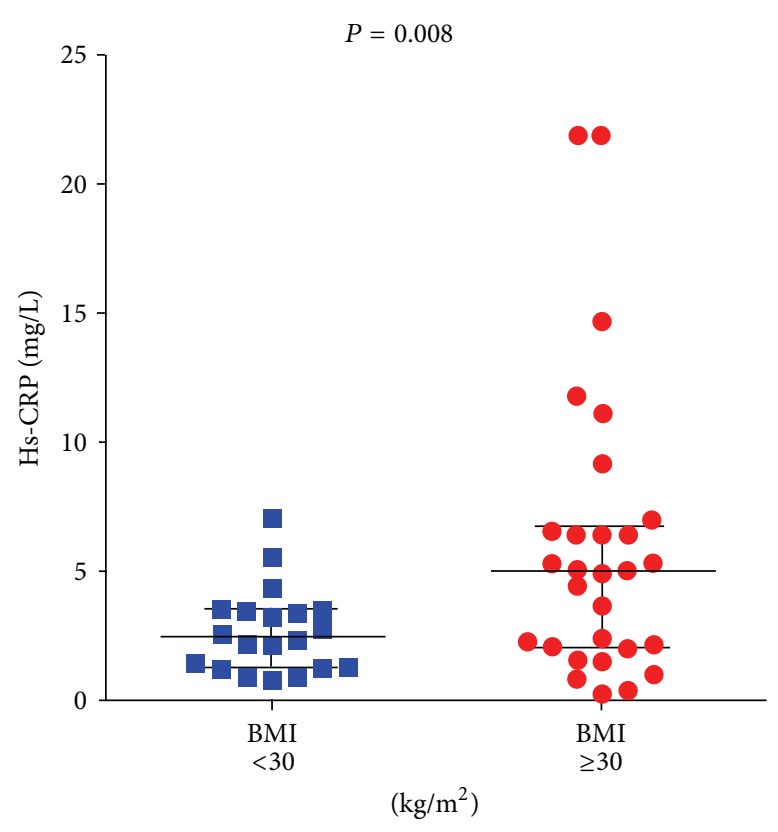

(b)

FIGURE 7: Correlation between serum hs-CRP levels and BMI in T2DM patients. T2DM patients were defined as in Figure 1. Data are presented as single data points. (a) Positive correlation was statistically found between serum hs-CRP levels and BMI in T2DM patients. (b) Obese T2DM patients (BMI $\left.\geq 30 \mathrm{~kg} / \mathrm{m}^{2}\right)$ showed higher levels of serum hs-CRP than nonobese $\left(\mathrm{BMI}<30 \mathrm{~kg} / \mathrm{m}^{2}\right) \mathrm{T} 2 \mathrm{DM}$ patients.

insulin resistance and consequently T2DM, as shown by several studies demonstrating that high levels of inflammation markers (including CRP, fibrinogen, IL-6, and plasminogen activator inhibitor PAI-1) could predict the risk of developing T2DM [7, 8, 11, 12]. CRP is now recognized as a sensitive and useful, although nonspecific, marker of cardiovascular risk [16]. In our work, we found higher levels of hs-CRP in T2DM patients, with values of hs-CRP approximately similar in T1DM and in controls. Moreover, we observed higher levels of hs-CRP in those T2DM patients with overt macrovascular complications. Recent studies highlighted the correlation between high levels of CRP and IL-1 $\beta$ in diabetic patients. A statistically significant reduction in CRP, IL-6, and other inflammatory biomarkers was observed after the administration of anti-IL-1 $\beta$ antibodies in T2DM patients, suggesting a prominent role of this cytokine in the induction of the chronic inflammatory state characterizing the disease $[47,48]$ and its possible involvement in the subsequent alteration of the adaptive immune response [49].

The role of the adaptive immune system has also been investigated in the pathogenesis of T1DM and T2DM. Particularly, a disregulation of T-cell compartment seems to be a pivotal feature of both the diseases.

$\mathrm{CD} 4{ }^{+} \mathrm{CD} 28^{\text {null }}$ T-cells, extremely unusual in healthy adults, are expanded in chronic inflammatory disorders such as rheumatoid arthritis. These T-cells have a prominent Thl phenotype, producing high levels of IFN- $\gamma$, are resistant to apoptosis, and represent a marker of senescence of the immune system $[26,27]$. In the atherosclerotic plaque microenvironment, $\mathrm{CD} 4^{+} \mathrm{CD} 28^{\text {null }} \mathrm{T}$-cells have direct cytolytic effects on endothelial cells and proapoptotic effects on smooth muscle cells; thus, they might contribute to plaque instability $[29,30]$. In $\mathrm{ACS}, \mathrm{CD} 4^{+} \mathrm{CD} 28^{\text {null }}$ T-cell frequency has been associated with the recurrence of acute coronary events [31]. In DM patients, $\mathrm{CD} 4^{+} \mathrm{CD} 28^{\text {null }} \mathrm{T}$-cells are expanded and are associated with poor glycemic control, with the occurrence of a first cardiovascular event and with a worse outcome after an ACS [32].

At the other extreme, $\mathrm{CD} 4^{+} \mathrm{CD} 25^{+} \mathrm{Foxp}^{+}$regulatory Tcells (Tregs) have a key role in the suppression of pathological inflammatory and immune responses. Their frequency is reduced in several autoimmune diseases and also in ACS [40, 50-52]. Recently, we have observed that a large subset of ACS patients presents a unique adaptive immunity system signature, associated to a worse outcome and characterized by inadequate Treg response to effector T-cell expansion [52].

Although $\mathrm{CD} 4^{+} \mathrm{CD} 28^{\text {null }} \mathrm{T}$-cells have been implicated in several immunological disorders, no previous studies have assessed the role of this T-cell subset in T1DM. More importantly, in the present study, we have systematically explored the balance between aggressive effector $\mathrm{T}$ cells/regulatory $\mathrm{T}$ cells by comparing patients with T1DM and T2DM. An altered immune balance has been found in both T1DM and T2DM, although with substantial differences.

In the present study, T1DM patients were characterized by higher $\mathrm{CD} 4{ }^{+} \mathrm{CD} 28^{\text {null }} \mathrm{T}$-cell frequency and lower Treg frequency, by a strikingly higher $\mathrm{CD} 4^{+} \mathrm{CD} 28^{\text {null }} /$ Treg ratio, and by a negative correlation between $\mathrm{CD} 4^{+} \mathrm{CD} 28^{\text {null }} \mathrm{T}$-cells and Tregs. These findings suggest the preferential association of increased $\mathrm{CD} 44^{+} \mathrm{CD} 28^{\text {null }}$ T-cell immune response with impaired Treg function in single T1DM patients. All together, 
our data suggest that, in the altered response of adaptive immunity involved in the pathogenesis of T1DM, a role might be reserved to special subset of T-cells, which could represent both the triggering factor and the continuing stimulus sustaining the disease. On the other hand, in T2DM, an imbalance in the adaptive immunity seems to appear later in the course of the disease as a consequence of a chronic systemic inflammatory state that is involved both in the pathogenesis of the disease and in its macrovascular complications. In fact, an altered adaptive immunity is also present in $\mathrm{T} 2 \mathrm{DM}$ patients with $\mathrm{CD} 4^{+} \mathrm{CD} 28^{\text {null }}$ T-cell frequency higher and Treg frequency lower than in controls, but it seems to be strictly related to disease duration and glycemic control rather than being a mechanism involved in the early phase of the disease. In our previous study, we demonstrated that the expansion of $\mathrm{CD} 4^{+} \mathrm{CD} 28^{\text {null }}$ T-cells in T2DM patients is independently associated with $\mathrm{HbAlc}$ levels and not with fasting glucose [32]. This suggests that the development of unusual T-cell subsets might be influenced by persistent poor glycemic control and might be presumably related to the presence of high levels of AGEs, known to be implicated in the onset of DM vascular complications [14].

\section{Conclusions}

Our study demonstrates that both T1DM and T2DM are associated with an impaired T-cell balance, characterized by $\mathrm{CD} 4^{+} \mathrm{CD} 28^{\text {null }}$ T-cell expansion and $\mathrm{CD} 4^{+} \mathrm{CD} 25^{+} \mathrm{Foxp}^{+}$ regulatory T-cell reduction. However, the meaning of these imbalances might be different between the two diseases. In fact, the altered adaptive immunity found in T1DM seems to be both the triggering factor and the continuing stimulus sustaining the disease, while in T2DM the same disregulation seems to appear later in the course of the disease, as consequence of a persistent poor glycemic control and of a chronic systemic inflammatory state which is associated with overt macrovascular complications.

Our results pave the way to a novel explanation for the possible role of adaptive immune system in the development of T1DM and T2DM, which could also have important implications in the prevention and treatment of diabetes and its cardiovascular complications. Interestingly, recent trials showed that IL-1 $\beta$ neutralising antibodies improve glycemic control and reduce inflammation in patients with T2DM $[47,48]$. Further studies are needed to ascertain whether the defective number of Tregs is part of the causation leading to T1DM or an epiphenomenon. In the meantime, a number of immunomodulatory intervention trials have now been conducted in patients at risk for or with recent onset T1DM, often with the goal of restoring immune tolerance by inducing Tregs [53-55].

\section{References}

[1] S. Wild, G. Roglic, A. Green, R. Sicree, and H. King, "Global prevalence of diabetes: estimates for the year 2000 and projections for 2030," Diabetes Care, vol. 27, no. 5, pp. 1047-1053, 2004.
[2] American Diabetes Association, "Diagnosis and classification of diabetes mellitus," Diabetes Care, vol. 31, supplement 1, pp. S55-S60, 2008.

[3] S. M. Haffner, S. Lehto, T. Rönnemaa, K. Pyörälä, and M. Laakso, "Mortality from coronary heart disease in subjects with type 2 diabetes and in nondiabetic subjects with and without prior myocardial infarction," The New England Journal of Medicine, vol. 339, no. 4, pp. 229-234, 1998.

[4] S. R. Preis, S. J. Hwang, S. Coady et al., "Trends in all-cause and cardiovascular disease mortality among women and men with and without diabetes mellitus in the framingham heart study, 1950 to 2005," Circulation, vol. 119, no. 13, pp. 1728-1735, 2009.

[5] K. Malmberg, S. Yusuf, H. C. Gerstein et al., "Impact of diabetes on long-term prognosis in patients with unstable angina and non-Q-wave myocardial infarction: results of the OASIS (Organization to Assess Strategies for Ischemic Syndromes) Registry," Circulation, vol. 102, no. 9, pp. 1014-1019, 2000.

[6] S. M. Donahoe, G. C. Stewart, C. H. McCabe et al., "Diabetes and mortality following acute coronary syndromes," The Journal of the American Medical Association, vol. 298, no. 7, pp. 765-775, 2007.

[7] J. B. Meigs, F. B. Hu, N. Rifai, and J. A. E. Manson, "Biomarkers of endothelial dysfunction and risk of type 2 diabetes mellitus," The Journal of the American Medical Association, vol. 291, no. 16, pp. 1978-1986, 2004.

[8] R. B. Goldberg, "Cytokine and cytokine-like inflammation markers, endothelial dysfunction, and imbalanced coagulation in development of diabetes and its complications," The Journal of Clinical Endocrinology \& Metabolism, vol. 94, no. 9, pp. 31713182, 2009.

[9] M. A. Atkinson and G. S. Eisenbarth, “Type 1 diabetes: new perspectives on disease pathogenesis and treatment," The Lancet, vol. 358, no. 9277, pp. 221-229, 2001.

[10] G. Kroder, B. Bossenmaier, M. Kellerer et al., "Tumor necrosis factor alpha and hyperglycemia-induced insulin resistance," The Journal of Clinical Investigation, vol. 97, no. 6, pp. 1471-1477, 1996.

[11] A. D. Pradhan, J. E. Manson, N. Rifai, J. E. Buring, and P. M. Ridker, "C-reactive protein, interleukin 6, and risk of developing type 2 diabetes mellitus," Journal of the American Medical Association, vol. 286, no. 3, pp. 327-334, 2001.

[12] D. J. Freeman, J. Norrie, M. J. Caslake et al., "C-reactive protein is an independent predictor of risk for the development of diabetes in the West of Scotland Coronary Prevention Study," Diabetes, vol. 51, no. 5, pp. 1596-1600, 2002.

[13] K. Esposito, F. Nappo, R. Marfella et al., "Inflammatory cytokine concentrations are acutely increased by hyperglycemia in humans: role of oxidative stress," Circulation, vol. 106, no. 16, pp. 2067-2072, 2002.

[14] A. Goldin, J. A. Beckman, A. M. Schmidt, and M. A. Creager, "Advanced glycation end products: sparking the development of diabetic vascular injury," Circulation, vol. 114, no. 6, pp. 597605, 2006.

[15] L. M. Biasucci, G. Liuzzo, R. Della Bona et al., "Different apparent prognostic value of hs-CRP in type 2 diabetic and non-diabetic patients with acute coronary syndromes," Clinical Chemistry, vol. 55, no. 2, pp. 365-368, 2009.

[16] S. Kaptoge, E. di Angelantonio, L. Pennells et al., "C-reactive protein, fibrinogen, and cardiovascular disease prediction," The New England Journal of Medicine, vol. 367, no. 14, pp. 1310-1320, 2012. 
[17] J. A. Beckman, M. A. Creager, and P. Libby, "Diabetes and atherosclerosis: epidemiology, pathophysiology, and management," Journal of the American Medical Association, vol. 287, no. 19, pp. 2570-2581, 2002.

[18] G. Orasanu and J. Plutzky, "The pathologic continuum of diabetic vascular disease," Journal of the American College of Cardiology, vol. 53, no. 5, supplement, pp. S35-S42, 2009.

[19] F. K. Swirski and M. Nahrendorf, "Leukocyte behavior in atherosclerosis, myocardial infarction, and heart failure," Science, vol. 339, no. 6116, pp. 161-166, 2013.

[20] P. Libby, "Inflammation in atherosclerosis," Arteriosclerosis, Thrombosis, and Vascular Biology, vol. 32, no. 9, pp. 2045-2051, 2012.

[21] F. Crea and G. Liuzzo, "Pathogenesis of acute coronary syndromes," Journal of the American College of Cardiology, vol. 61, no. 1, pp. 1-11, 2013.

[22] C. Zeng, X. Shi, B. Zhang et al., "The imbalance of Th17/Th1/Tregs in patients with type 2 diabetes: relationship with metabolic factors and complications," Journal of Molecular Medicine, vol. 90, no. 2, pp. 175-178, 2012.

[23] M. Jagannathan-Bogdan, M. E. McDonnell, H. Shin et al., "Elevated proinflammatory cytokine production by a skewed $\mathrm{T}$ cell compartment requires monocytes and promotes inflammation in type 2 diabetes," Journal of Immunology, vol. 186, no. 2, pp. 1162-1172, 2011.

[24] S. Winer, Y. Chan, and G. Paltser, "Normalization of obesityassociated insulin resistance through immunotherapy," Nature Medicine, vol. 15, no. 8, pp. 921-929, 2009.

[25] H. Zhang, B. J. Potter, J. M. Cao, and C. Zhang, "Interferongamma induced adipose tissue inflammation is linked to endothelial dysfunction in type 2 diabetic mice," Basic Research in Cardiology, vol. 106, no. 6, pp. 1135-1145, 2011.

[26] G. Liuzzo, S. L. Kopecky, R. L. Frye et al., "Perturbation of the T-cell repertoire in patients with unstable angina," Circulation, vol. 100, no. 21, pp. 2135-2139, 1999.

[27] G. Liuzzo, J. J. Goronzy, H. Yang et al., "Monoclonal T-cell proliferation and plaque instability in acute coronary syndromes," Circulation, vol. 101, no. 25, pp. 2883-2888, 2000.

[28] B. Zal, J. C. Kaski, G. Arno et al., "Heat-shock protein 60reactive $\mathrm{CD} 44^{+} \mathrm{CD} 28^{\text {null }} \mathrm{T}$ Cells in patients with acute coronary syndromes," Circulation, vol. 109, no. 10, pp. 1230-1235, 2004.

[29] T. Nakajima, S. Schulte, K. J. Warrington et al., “T-cell-mediated lysis of endothelial cells in acute coronary syndromes," Circulation, vol. 105, no. 5, pp. 570-575, 2002.

[30] S. Pryshchep, K. Sato, J. J. Goronzy, and C. M. Weyand, “T cell recognition and killing of vascular smooth muscle cells in acute coronary syndrome," Circulation Research, vol. 98, no. 9, pp. 1168-1176, 2006.

[31] G. Liuzzo, L. M. Biasucci, G. Trotta et al., "Unusual $\mathrm{CD} 4{ }^{+} \mathrm{CD} 28^{\text {null }} \mathrm{T}$ lymphocytes and recurrence of acute coronary events," Journal of the American College of Cardiology, vol. 50, no. 15, pp. 1450-1458, 2007.

[32] S. Giubilato, G. Liuzzo, S. Brugaletta et al., "Expansion of $\mathrm{CD} 4{ }^{+} \mathrm{CD} 28^{\text {null }}$ T-lymphocytes in diabetic patients: exploring new pathogenetic mechanisms of increased cardiovascular risk in diabetes mellitus," European Heart Journal, vol. 32, no. 10, pp. 1214-1226, 2011.

[33] M. Feuerer, L. Herrero, D. Cipolletta et al., "Lean, but not obese, fat is enriched for a unique population of regulatory $\mathrm{T}$ cells that affect metabolic parameters," Nature Medicine, vol. 15, no. 8, pp. 930-939, 2009.
[34] K. Eller, A. Kirsch, and A. M. Wolf, "Potential role of regulatory $\mathrm{T}$ cells in reversing obesity-linked insulin resistance and diabetic nephropathy," Diabetes, vol. 60, no. 11, pp. 2954-2962, 2011.

[35] K. Wing and S. Sakaguchi, "Regulatory T cells exert checks and balances on self tolerance and autoimmunity," Nature Immunology, vol. 11, no. 1, pp. 7-13, 2010.

[36] A. Ferraro, C. Socci, A. Stabilini et al., "Expansion of Th17 cells and functional defects in Tregulatory cells are key features of the pancreatic lymph nodes in patients with type 1 diabetes," Diabetes, vol. 60, no. 11, pp. 2903-2913, 2011.

[37] S. Sakaguchi, M. Ono, R. Setoguchi et al., "Foxp3 ${ }^{+}$CD25 $5^{+}$ $\mathrm{CD}^{+}$natural regulatory $\mathrm{T}$ cells in dominant self-tolerance and autoimmune disease," Immunological Reviews, vol. 212, no. 1, pp. $8-27,2006$.

[38] Q. Tang, J. Y. Adams, C. Penaranda et al., "Central role of defective interleukin-2 production in the triggering of islet autoimmune destruction," Immunity, vol. 28, no. 5, pp. 687-697, 2008.

[39] S. Sakaguchi, M. Miyara, C. M. Costantino, and D. A. Hafler, "FOXP $3^{+}$regulatory T cells in the human immune system," Nature Reviews Immunology, vol. 10, no. 7, pp. 490-500, 2010.

[40] A. Mor, G. Luboshits, D. Planer, G. Keren, and J. George, "Altered status of $\mathrm{CD} 4{ }^{+} \mathrm{CD} 25^{+}$regulatory $\mathrm{T}$ cells in patients with acute coronary syndromes," European Heart Journal, vol. 27, no. 21, pp. 2530-2537, 2006.

[41] H. Ait-Oufella, B. L. Salomon, S. Potteaux et al., "Natural regulatory $\mathrm{T}$ cells control the development of atherosclerosis in mice," Nature Medicine, vol. 12, no. 2, pp. 178-180, 2006.

[42] Y. Zhang, E. Bandala-Sanchez, and L. C. Harrison, "Revisiting regulatory T cells in type 1 diabetes," Current Opinion in Endocrinology, Diabetes, and Obesity, vol. 19, no. 4, pp. 271-278, 2012.

[43] M. I. Harris, K. M. Flegal, C. C. Cowie et al., "Prevalence of diabetes, impaired fasting glucose, and impaired glucose tolerance in U.S. adults: the Third National Health and Nutrition Examination Survey, 1988-1994," Diabetes Care, vol. 21, no. 4, pp. 518-524, 1998.

[44] J. C. Pickup and M. B. Mattock, "Activation of the innate immune system as a predictor of cardiovascular mortality in type 2 diabetes mellitus," Diabetic Medicine, vol. 20, no. 9, pp. 723-726, 2003.

[45] D. Bending, P. Zaccone, and A. Cooke, "Inflammation and type one diabetes," International Immunology, vol. 24, no. 6, pp. 339346, 2012.

[46] M. Wegner, A. Araszkiewicz, M. Piorunska-Stolzmann, B. Wierusz-Wysocka, and D. Zozulinska-Ziolkiewicz, "Association between IL- 6 concentration and diabetes-related variables in DM1 patients with and without microvascular complications," Inflammation, 2013.

[47] C. Cavelti-Weder, A. Babians-Brunner, C. Keller et al., "Effects of gevokizumab on glycemia and inflammatory markers in type 2 diabetes," Diabetes Care, vol. 35, no. 8, pp. 1654-1662, 2012.

[48] P. M. Ridker, C. P. Howard, V. Walter et al., "Effects of interleukin- $1 \beta$ inhibition with canakinumab on hemoglobin Alc, lipids, C-reactive protein, interleukin-6, and fibrinogen: a phase IIb randomized, placebo-controlled trial," Circulation, vol. 126, no. 23, pp. 2739-2748, 2012.

[49] C. Dostert, K. Ludigs, and G. Guarda, "Innate and adaptive effects of inflammasomes on T cell responses," Current Opinion in Immunology, 2013. 
[50] S. F. Han, P. Liu, W. Zhang et al., "The opposite-direction modulation of $\mathrm{CD} 4{ }^{+} \mathrm{CD} 25^{+}$Tregs and T helper 1 cells in acute coronary syndromes," Clinical Immunology, vol. 124, no. 1, pp. 90-97, 2007.

[51] X. Cheng, X. Yu, Y. J. Ding et al., “The Th17/Treg imbalance in patients with acute coronary syndrome," Clinical Immunology, vol. 127, no. 1, pp. 89-97, 2008.

[52] G. Liuzzo, R. A. Montone, M. Gabriele et al., "Identification of unique adaptive immune system signature in acute coronary syndromes," International Journal of Cardiology, 2013.

[53] G. T. Nepom, M. Ehlers, and T. Mandrup-Poulsen, "Anticytokine therapies in T1D: concepts and strategies," Clinical Immunology, 2013.

[54] A. L. Putnam, T. M. Brusko, M. R. Lee et al., "Expansion of human regulatory T-cells from patients with type 1 diabetes," Diabetes, vol. 58, no. 3, pp. 652-662, 2009.

[55] M. A. Hulme, C. H. Wasserfall, M. A. Atkinson, and T. M. Brusko, "Central role for interleukin-2 in type 1 diabetes," Diabetes, vol. 61, no. 1, pp. 14-22, 2012. 


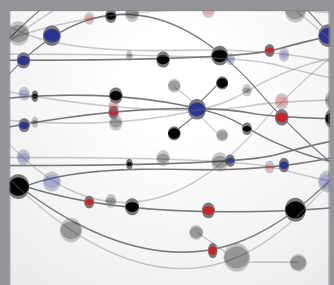

The Scientific World Journal
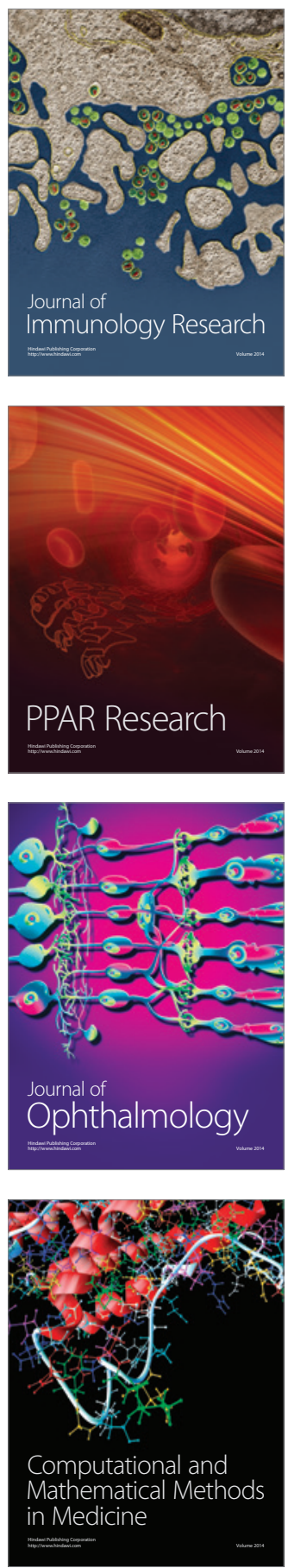

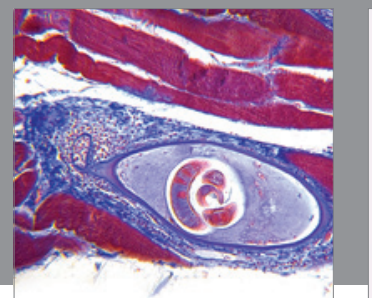

Gastroenterology

Research and Practice
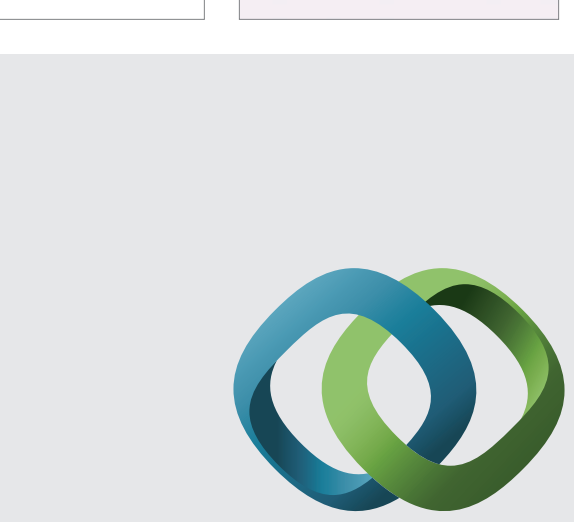

\section{Hindawi}

Submit your manuscripts at

http://www.hindawi.com
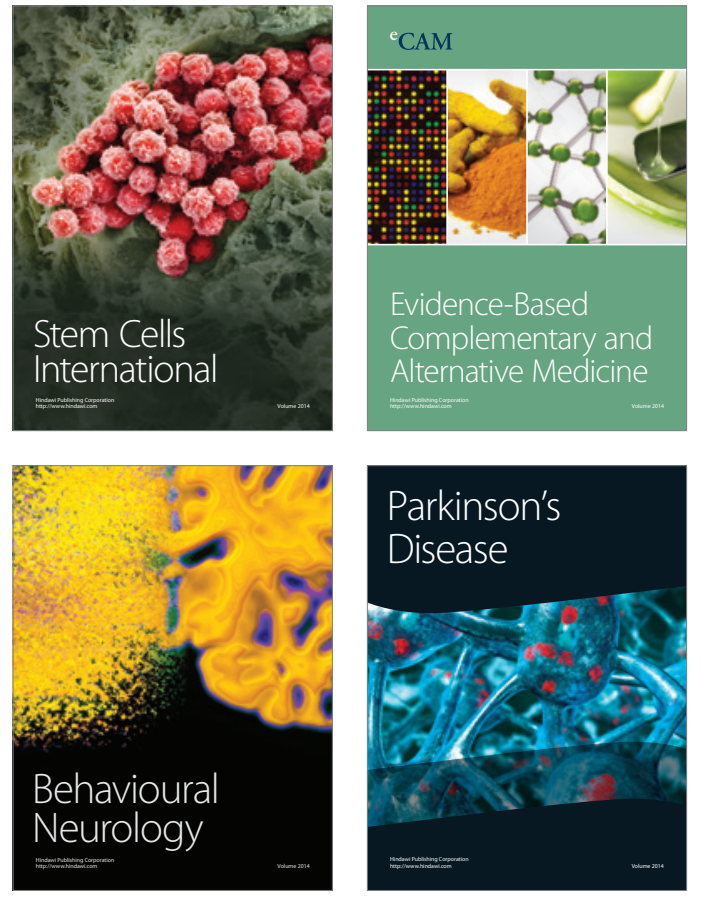
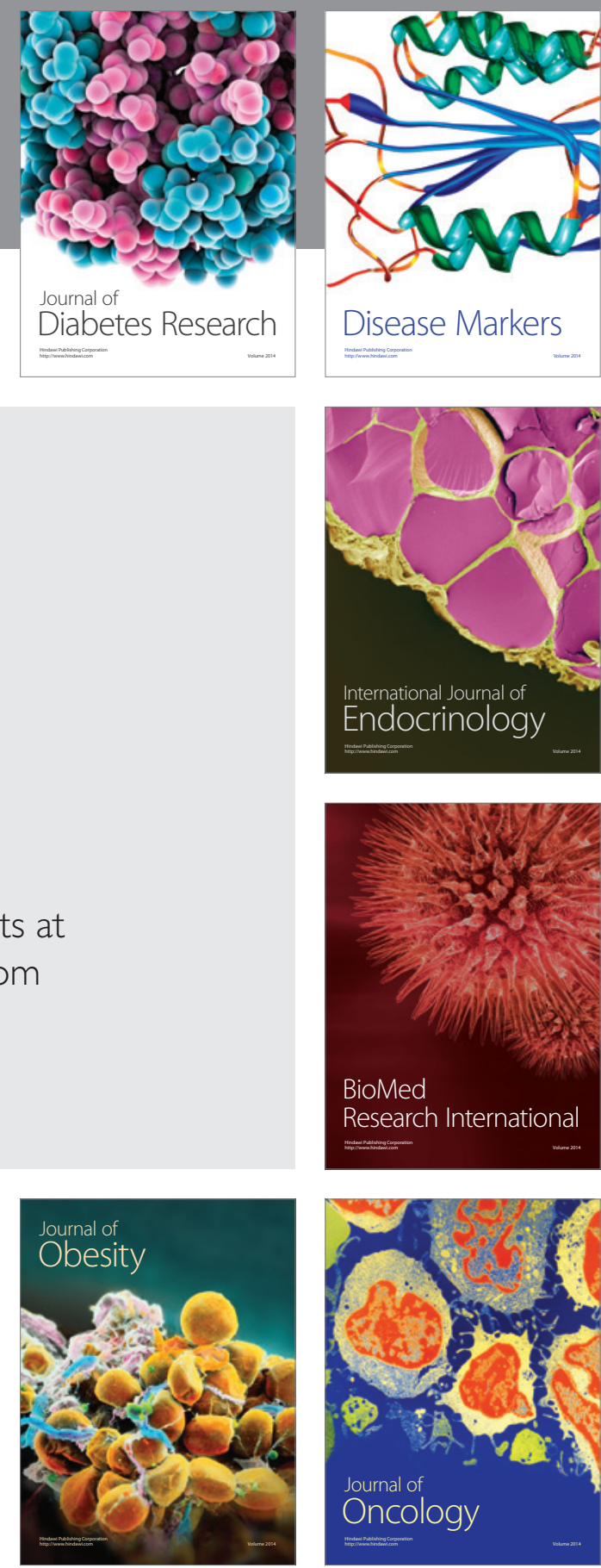

Disease Markers
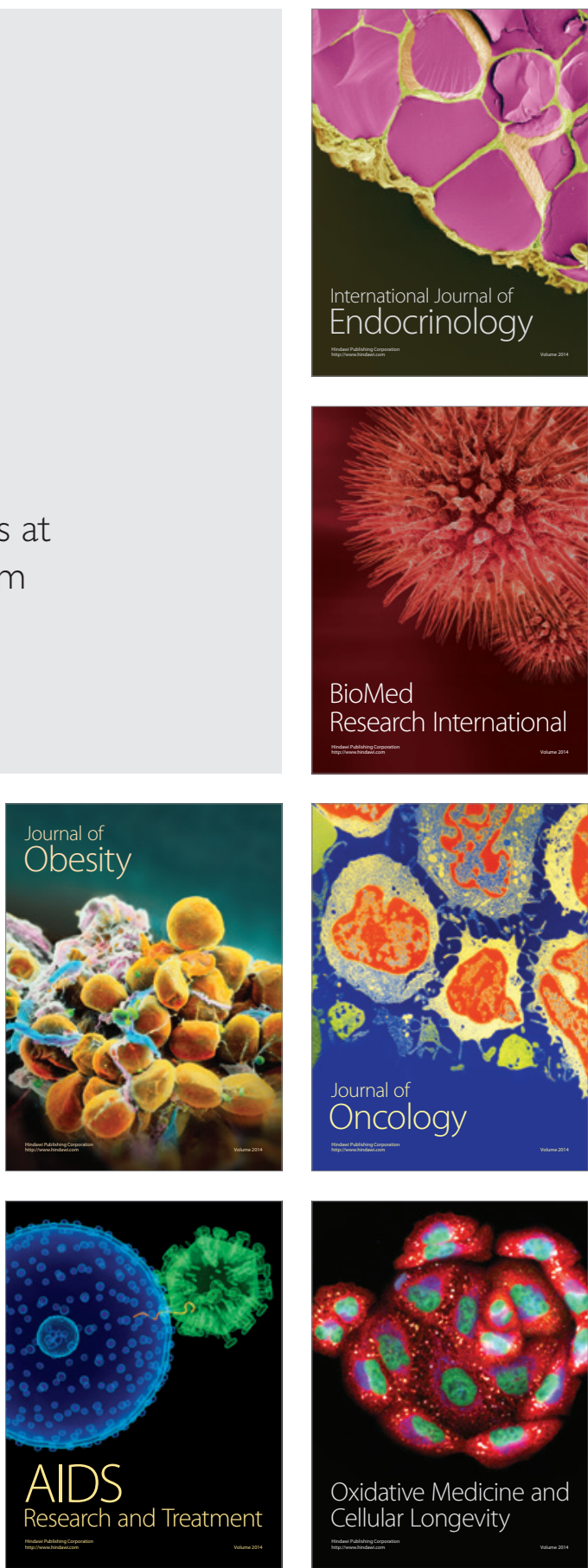